\title{
RESEARCH RESULTS OF EXPERIMENTAL AUTOMATED SYSTEM FOR DOSING BULK MATERIALS
}

\author{
Sergey Bulatov ${ }^{1}$, Vladimir Nechaev ${ }^{2}$, Peter Savinyh ${ }^{3}$, Adolfs Rucins ${ }^{4}$
}

${ }^{1}$ Nizhegorod State Engineering and Economic University, Russia; ${ }^{2}$ Vyatka State University, Russia;

${ }^{3}$ North-East Agricultural Research Institute, Russia; ${ }^{4}$ Latvia University of Life Sciences and

Technologies, Latvia

semjons@apollo.lv, adolfs.rucins@llu.lv

\begin{abstract}
Automated systems for dosing bulk materials are widely used in agriculture, but the issue of measurement accuracy remains relevant. The studies were carried out on a developed laboratory setup. The results of the installation were investigated when dosing various bulk materials- softwood sawdust, wood flour, wood shavings. After processing the results of the conducted studies, regression models are constructed showing the influence of the parameters of the automated dosing system on its accuracy of weighing the materials under study. Work on the auger series DS-100 with size: step turns $90 \mathrm{~mm}$, outer screw diameter $100 \mathrm{~mm}$, height of the pen spiral $29 \mathrm{~mm}$. The influence of the parameters of the dosing system on its weighing accuracy was studied. Experimental studies were conducted using the theory of experimental planning Box-Behnken design was implemented for four factors. When choosing the intervals of the studied parameters, we proceeded from the minimum and maximum values of the parameters set in the control program of the dosing system. The adequacy of the constructed models is shown. The parameters that have the greatest influence on the relative error of weighing the automated system are determined. The zones in which the system operation meets the requirements for metering devices are highlighted. Recommendations are given for choosing the optimal values of the parameters of the dosing system when weighing sawdust of coniferous species. With the help of the DS-100 series dispenser, it is possible to dose wood flour and sawdust with a mass of $1 \mathrm{~kg}$ with an error not exceeding $5 \%$.
\end{abstract}

Keywords: dosing, weighing, materials, systems.

\section{Introduction}

Weighing systems for various materials and substances are widely used in all spheres of human life. Bulk materials are an integral part of a person's life. In a large number of cases, such materials are part of a large system and are introduced into it in certain quantities. Usually, for a given input of bulk materials, weighing and dosing systems are used. Such systems are widely used in all spheres of human life: in the food industry [1;2]; in the construction sector [3]; in mining and oilfield processes [4;5] and other areas [6; 7]. Perhaps the most widespread dispensers of bulk materials were in agriculture [8-9].

Currently, many companies in various countries are engaged in the development of weighing systems. Such companies include AEG (Germany), Bühler AG (Switzerland), Van Aarsen International BV (Netherlands), the Tenzo-M weighing company (Russia.), Techneks engineering company (Russia) and others [10-12]. Considerable attention is also paid to the issues of calculating weighing systems. The dosing process was modeled by Chadha G., Schulze D., Mills H., OI Imole O. Shimizu Y., D. Aufderheide, Miculec M. [13-18].

Currently, people tend to automate such systems in order to facilitate human labor. But due to the huge number of materials and substances with different physical and mechanical properties, it is necessary to conduct a preliminary calibration of the system for a specific material. To simplify this process, we need a database on the operation of such systems when weighing various materials. The purpose of the work is to study the operation of an automated system for dosing bulk materials.

\section{Materials and methods}

The bulk material dosing system includes: storage hopper, which is mounted on load cells; auger, which takes the material from the receiving bins and feeds it to the storage hopper; automated control system (Fig. 1). The automated system controls the operation of the screw motor, monitors the process of weighing materials. The accuracy of dosing is achieved by selecting the values of several parameters entered in the program.

The results of the installation were investigated when dosing various bulk materials - softwood sawdust, wood flour, wood shavings. After processing the results of the conducted studies, regression models are constructed showing the influence of the parameters of the automated dosing system on its accuracy of weighing the materials under study. Work on the auger series DS-100 with size: step turns $90 \mathrm{~mm}$, outer screw diameter $100 \mathrm{~mm}$, height of the pen spiral $29 \mathrm{~mm}$. 


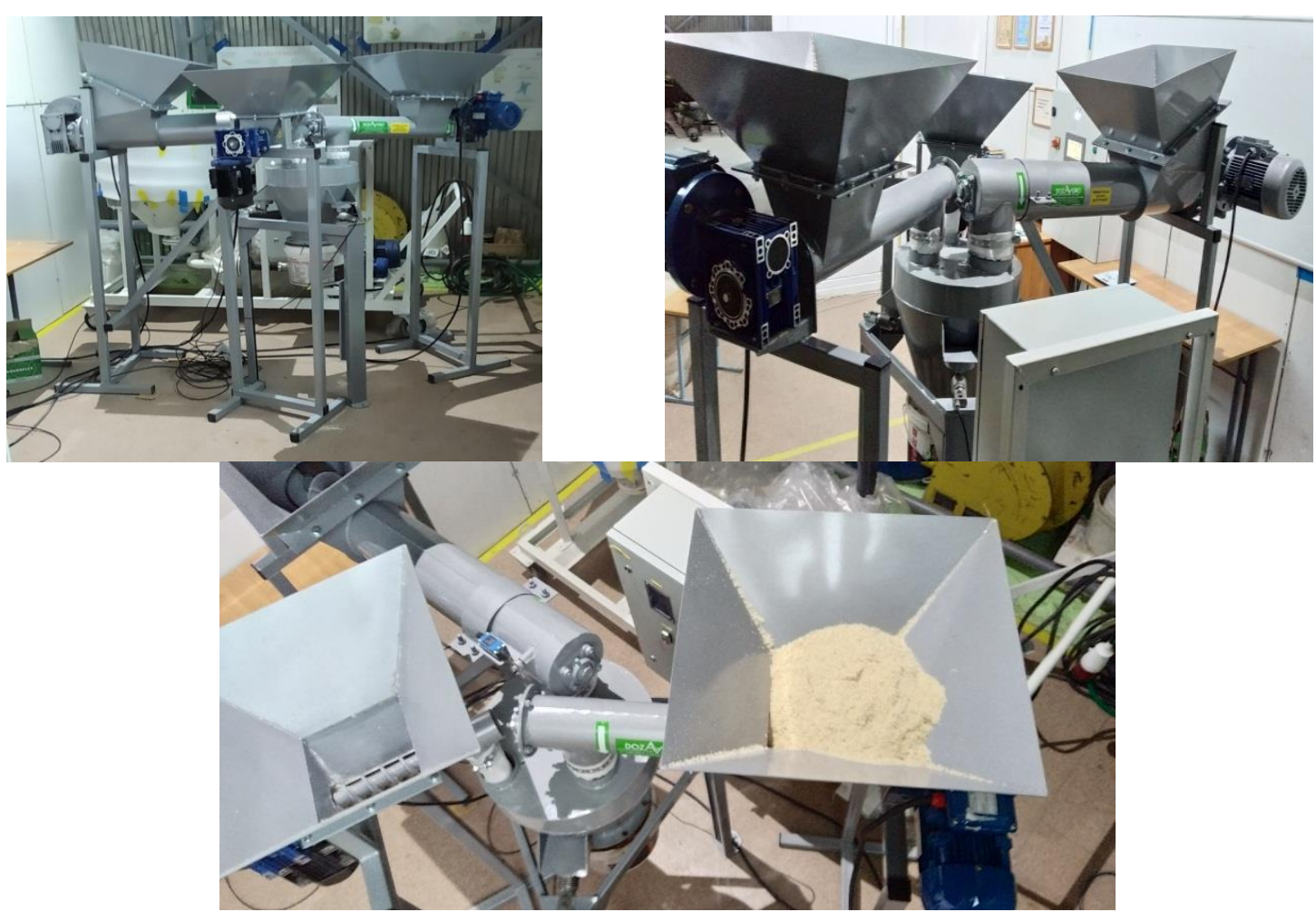

Fig. 1. Laboratory installation for dosing of sawn materials

The influence of four factors included in the program and responsible for the operation of the unit on the dosing accuracy was investigated. One of the main factors is the main rotation speed $n_{1}$ (factor $A$ ) of the dispenser screw. At this frequency, the main feed of the material takes place. The speed of rotation of the screw is changed by the program through the frequency converter built into the control cabinet. To change $n_{1}$ in the program menu, we must set the value from 0 to $50 \mathrm{~Hz}$, which corresponds to the minimum and maximum values of the screw speed. During the experiment, the widest possible range of values was taken. The minimum value of the parameter $A$ was set to $10 \mathrm{~Hz}$, and the maximum value was set to $50 \mathrm{~Hz}$. By the end of the dosing process, the program switches the screw speed to a lower $n_{2}$ (factor $D$ ). This rotation frequency is called the filling speed. It is lower than the main one. Since the program does not allow $n_{2}$ to set more than $n_{1}$, during the experiment, $n_{2}$ was set as a percentage of $n_{1}$. The minimum value of the factor $D$ was $10 \%$, and the maximum value was $100 \%$ of the factor $A$. The switching time from $n_{1}$ to $n_{2}$ is also set in the program as a percentage of the bulk of the dosed material (factor $C$ ). This factor has changed from $10 \%$ to $90 \%$. That is, when setting the minimum value (10\%), switching from $n_{1}$ to $n_{2}$ occurred, when it was necessary to fill up $10 \%$ of the material to the specified mass. Load cells transmit readings of the material that is in the hopper. But they cannot account for the weight of the material that is in the fall. The action of the material that is in the fall takes into account the factor $B$. This factor is entered in the program with the dimension "kilogram". The heavier the material, the higher the value of this factor should be. During the experiments, the boundary values of the factor $B$, equal to 0.1 and $0.5 \mathrm{~kg}$, were taken.

The evaluation of the operation of the bulk material dosing system was carried out in terms of the relative weighing error 4 , expressed as a percentage and determined by the formula 1 :

$$
\delta=\frac{\left(m-m_{1}\right)}{m} \cdot 100 \%,
$$

where $m$ - mass of the hitch, $\mathrm{kg}$;

$m_{1}-$ mass of the hitch weighted by system, $\mathrm{kg}$.

Studies of the dosing system were carried out on the following materials: wood chips, sawdust of coniferous trees, wood flour. The main characteristics of the materials are presented in Table 1. Sawdust passed through a sieve with holes of $0.5 \mathrm{~mm}$ was attributed to wood flour. 
Characteristics of the investigated materials

Table 1

\begin{tabular}{|c|c|c|c|c|}
\hline \multirow{2}{*}{ Material name } & \multicolumn{4}{|c|}{ Material parameters } \\
\cline { 2 - 5 } & Density, $\mathrm{kg} \cdot \mathrm{m}^{-3}$ & $\begin{array}{c}\text { Natural angle of the } \\
\text { bevel, the degree }\end{array}$ & $\begin{array}{c}\text { Weighted average } \\
\text { size, } \mathrm{mm}\end{array}$ & $\begin{array}{c}\text { Humidity, } \\
\%\end{array}$ \\
\hline Wood shavings & 51 & 54 & - & 13 \\
\hline Sawdust & 168 & 45 & 0.4 & 10 \\
\hline Wood flour & 100 & 46 & 0.32 & 9 \\
\hline
\end{tabular}

It is shown that the weighing error decreases with the increase in the weight of the hitch. Therefore, the experiments were carried out at the lowest possible weight of the suspension for the DS-100 screw under study, the value of which was $1 \mathrm{~kg}$. The studies used standard and applied techniques for measuring and recording parameters, the results were processed in the program Statgraphics [19-21].

\section{Results and discussion}

The results of the experiments are presented in Table 2.

Table 2

Plan and results of the experiment when dosing wood flour, sawdust with a DS-100 auger

\begin{tabular}{|c|c|c|c|c|c|}
\hline \multicolumn{3}{|c|}{ Factors } & \multicolumn{3}{c|}{ Optimization criterion (related error when dosing $\boldsymbol{\delta}, \boldsymbol{\%})$} \\
\hline$A$ & $B$ & $C$ & $D$ & Sawdust & Wood flour \\
\hline 30.0 & 0.3 & 50.0 & 55.0 & -17.8 & -16.6 \\
\hline 10.0 & 0.1 & 50.0 & 55.0 & -6.6 & -6.6 \\
\hline 50.0 & 0.1 & 50.0 & 55.0 & 17.0 & 21.7 \\
\hline 10.0 & 0.5 & 50.0 & 55.0 & -46.7 & -46.8 \\
\hline 50.0 & 0.5 & 50.0 & 55.0 & -10.7 & -2.3 \\
\hline 30.0 & 0.3 & 10.0 & 10.0 & -28.8 & -28.6 \\
\hline 30.0 & 0.3 & 90.0 & 10.0 & -5.4 & -0.9 \\
\hline 30.0 & 0.3 & 10.0 & 100.0 & -0.6 & 4.6 \\
\hline 30.0 & 0.3 & 90.0 & 100.0 & 0.0 & 3.5 \\
\hline 10.0 & 0.3 & 50.0 & 10.0 & -23.8 & -55.6 \\
\hline 50.0 & 0.3 & 50.0 & 10.0 & 5.0 & 12.4 \\
\hline 10.0 & 0.3 & 50.0 & 100,0 & -23.8 & -22.5 \\
\hline 50.0 & 0.3 & 50.0 & 100.0 & 36.5 & 35.0 \\
\hline 30.0 & 0.3 & 50.0 & 55.0 & -17.8 & -16.6 \\
\hline 30.0 & 0.1 & 10.0 & 55.0 & 3.2 & 3.7 \\
\hline 30.0 & 0.5 & 10.0 & 55.0 & -36.4 & -35.5 \\
\hline 30.0 & 0.1 & 90.0 & 55.0 & 13.4 & 15.8 \\
\hline 30.0 & 0.5 & 90.0 & 55.0 & -22.2 & -18.8 \\
\hline 10.0 & 0.3 & 10.0 & 55.0 & -26.9 & -25.4 \\
\hline 50.0 & 0.3 & 10.0 & 55.0 & -4.1 & 1.2 \\
\hline 10.0 & 0.3 & 90.0 & 55.0 & -26.3 & -26.1 \\
\hline 50.0 & 0.3 & 90.0 & 55.0 & 32.3 & 37.5 \\
\hline 30.0 & 0.1 & 50.0 & 10.0 & -8.9 & -8.4 \\
\hline 30.0 & 0.5 & 50.0 & 10.0 & -42.2 & -37.3 \\
\hline 30.0 & 0.1 & 50.0 & 100.0 & 20.9 & 24.2 \\
\hline 30.0 & 0.5 & 50.0 & 100.0 & -20.7 & -14.7 \\
\hline 30.0 & 0.3 & 50.0 & 55.0 & -17.8 & -16.6 \\
\hline & & & & & \\
\hline
\end{tabular}

During the experiment it was found that wood chips hang in the receiving hopper. Therefore, experiments with this material, when using the DS-100 auger, were not carried out. It is proposed to use augers with large dimensions for dosing wood chips. After processing the statistical data presented in 
Table 2, an equation describing the change in the accuracy of dosing softwood sawdust with a 95\% confidence probability is constructed:

$$
\begin{aligned}
\delta & =21.189-1.471 \cdot A-107.424 \cdot B-0.318 \cdot C-0.145 \cdot D+0.013 \cdot A^{2}+0.775 \cdot A \cdot B+0.011 \cdot A \cdot C+, \\
& +0.009 \cdot A \cdot D-0.313 \cdot B^{2}+0.125 \cdot B \cdot C-0.231 \cdot B \cdot D+0.003 \cdot C^{2}-0.003 \cdot C \cdot D+0.003 \cdot D^{2} .
\end{aligned}
$$

The coefficient of determination of the equation $R=94.5$ percent and Durbin-Watson statistic $D W=2.33$ indicates this model's adequacy. When analyzing the results of the experiment, 4 combinations of factors were identified, for which the optimization criterion is 0 (Table 3 ).

Table 3

Optimal combination of factors when dosing softwood sawdust

\begin{tabular}{|c|c|c|c|c|}
\hline \multirow{2}{*}{ Name } & \multicolumn{4}{|c|}{ Factor combinations } \\
\cline { 2 - 5 } & 1 & 2 & 3 & 4 \\
\hline Factor $A$ & 35.964 & 10.743 & 45.411 & 49.525 \\
\hline Factor $B$ & 0.201 & 0.104 & 0.491 & 0.107 \\
\hline Factor $C$ & 51.768 & 24.780 & 13.336 & 14.132 \\
\hline Factor $D$ & 62.959 & 76.157 & 97.402 & 25.906 \\
\hline Actual relative error, \% & 3.5 & 5 & 1.7 & 3 \\
\hline
\end{tabular}

The lowest actual relative error is observed for the third combination of factors and is $1.7 \%$ (Table 3). In general, for any combination of factors, the sawdust dosing error does not exceed 5\%.

The accuracy of dosing in this case is described by the regression model:

$$
\begin{aligned}
& \delta=-8.08-0.373 \cdot A-141.47 \cdot B-0.403 \cdot C+0.41 \cdot D+0.014 \cdot A^{2}+1.013 \cdot A \cdot B+0.012 \cdot A \cdot C- \\
& 0.0029 \cdot A \cdot D+56.354 \cdot B^{2}+0.144 \cdot B \cdot C-0.278 \cdot B \cdot D+0.004 \cdot C^{2}-0.004 \cdot C \cdot D+0.002 \cdot D^{2},
\end{aligned}
$$

The analysis of the equation indicates its adequacy: the coefficient of determination of the equation $R=93.2$ percent, Durbin-Watson statistic $D W=2.97$. The optimal combinations of the studied factors are determined, at which the zero value of the dosing error is achieved (Table 4).

Table 4

Optimal combination of factors when dosing wood flour

\begin{tabular}{|c|c|c|c|c|}
\hline \multirow{2}{*}{ Name } & \multicolumn{4}{|c|}{ Factor combinations } \\
\cline { 2 - 5 } & 1 & 2 & 3 & 4 \\
\hline Factor $A$ & 35.268 & 13.089 & 39.410 & 47.093 \\
\hline Factor $B$ & 0.212 & 0.108 & 0.469 & 0.121 \\
\hline Factor $C$ & 51.838 & 38.571 & 70.156 & 12.393 \\
\hline Factor $D$ & 61.429 & 76.566 & 90.725 & 11.01 \\
\hline Actual relative error, \% & 0 & 3 & 1 & 8.6 \\
\hline
\end{tabular}

When combining factors for combination 4 (Table 4), the dosing error exceeds $5 \%$, so this combination should be excluded. In general, regression models (1) and (2) have high coefficients of determination, which indicates the possibility of accepting hypotheses, that is, these models are adequate.

Experiments have shown that it is possible to achieve the minimum dosage error by several combinations of factors. However, it is necessary to take into account the fact that the system should not only provide accurate weighing, but also carry out this process as quickly as possible, that is, have a high throughput. Based on the characteristics of the control system, in order to achieve maximum throughput, it is necessary for the factors $A$ and $B$ to strive for maximum values, and the factor $C$ to the minimum. Based on this, the following recommended combinations were selected: for softwood sawdust - combination No. 4 (in accordance with Table 3), wood flour - combination No. 3 (in accordance with Table 4). Visualization of changes in the optimization criteria for optimal parameter values is shown in Fig. 2 and 3.

In general, the experimental results show that the DS-100 auger, which is controlled by an automated control program, can meter wood flour and sawdust of coiferous species weighing $1 \mathrm{~kg}$ with 
an acceptable error (no more than 5\%). And when dosing wood shavings, it is necessary to use large augers in order to prevent material from hanging in the storage hopper.
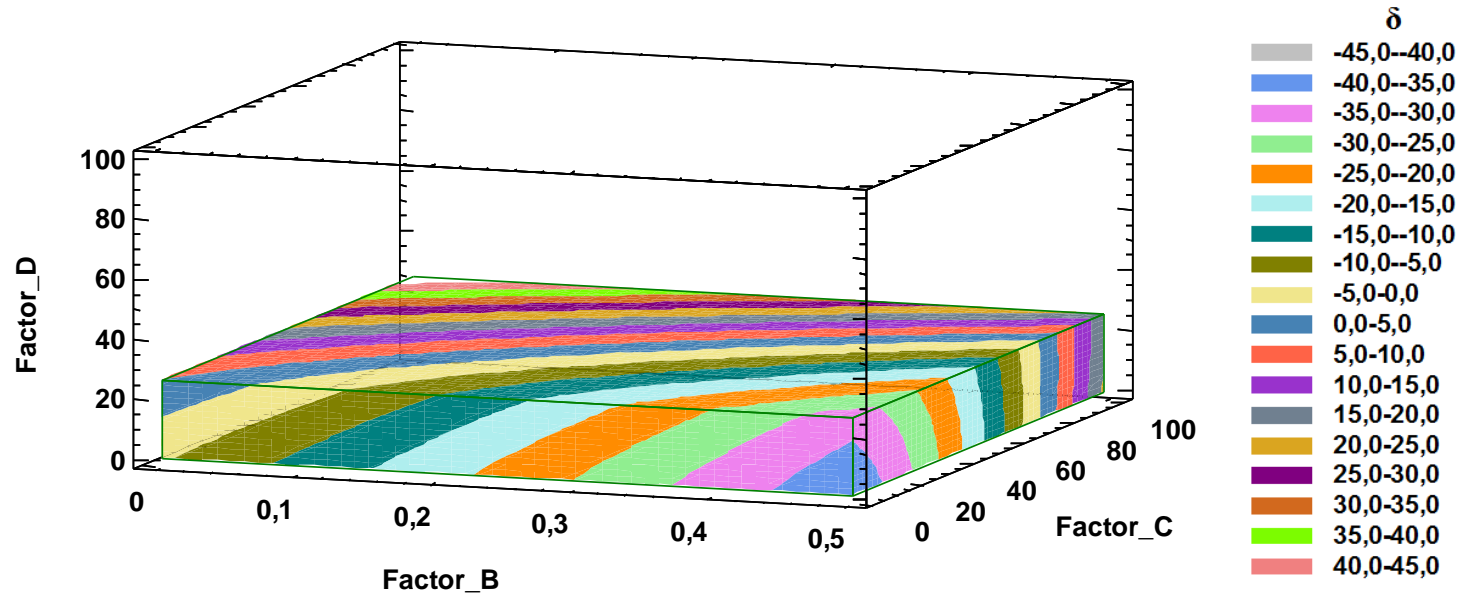

Fig. 2. Change in the dosing error of wood flour with a combination of factors No. 4 (in accordance with Table 3)

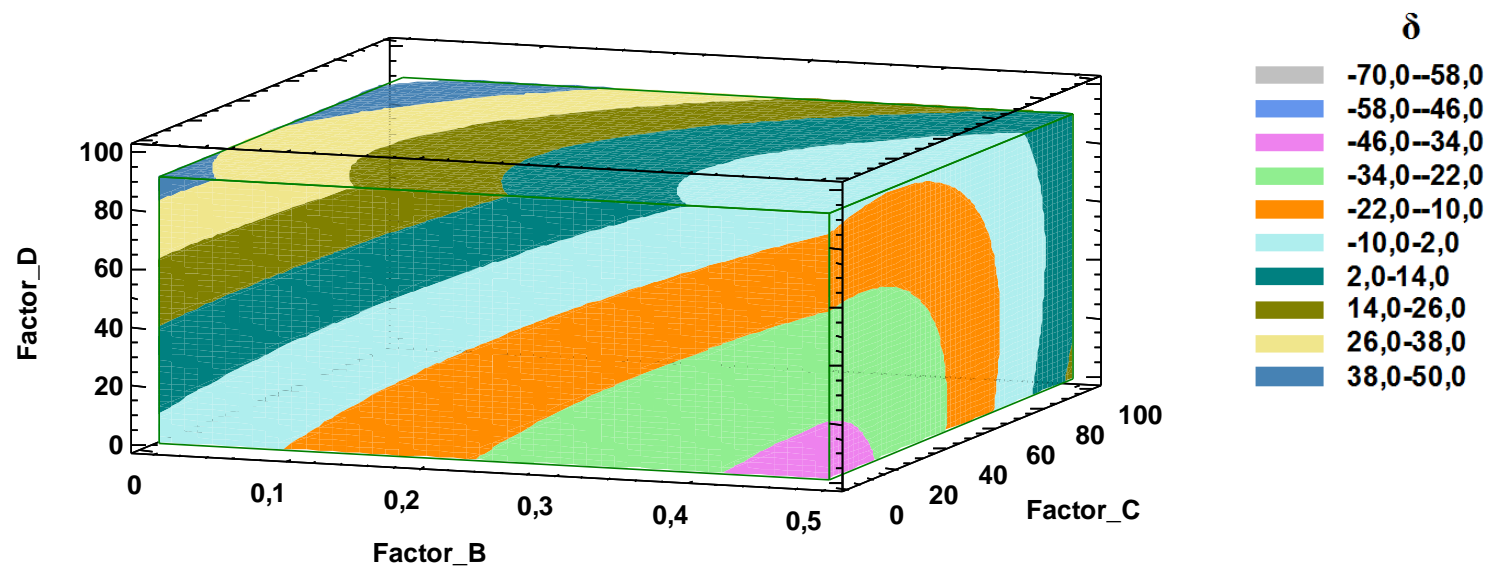

Fig. 3. Change in the dosing error of wood flour with a combination of factors No. 3 (in accordance with Table 4)

\section{Conclusions}

With the help of the DS-100 series dispenser it is possible to dose wood flour and sawdust with a mass of $1 \mathrm{~kg}$ with an error not exceeding 5\%. The optimal combinations of the studied factors are determined, at which the zero value of the dosing error is achieved. Due to hanging of wood chips in the receiving hopper, its dosing with the DS-100 auger is impossible. When dosing carpentry chips, it is necessary to use large augers in order to prevent the material from hanging in the storage hopper.

\section{References}

[1] Ladnorg U. Weighed and found good. Weighing and proportioning of bulk material. ZI, Ziegelindustrie International/Brick and Tile Industry International. Volume 46, Issue 5, 1993, pp. 315-317

[2] Norden E.K. Handbook of Electronic weighing. New York: John Wiley \& Sons, 2008

[3] Mien T.L._ A fuzzy PID-based cascade control for continuous material weighing conveyor. Advances in Science, Technology and Engineering Systems, 2019

[4] Каменских РР.А. Разработка установки глубинного дозатора с погружным контейнером. Актуальные проблемы повышения эффективности и безопасности эксплуатации горношахтного и нефтепромыслового оборудования (Development of a depth metering unit 
with a submersible container. Actual problems of improving the efficiency and safety of mining and oilfield equipment). 2017,. T. 1. pp. 53-60. (In Russian)

[5] Голованчиков А.Б., Прохоренко Н.А., Елфимова В.РР., Крюкова А.А. Модернизация весового дозатора. Вестник научных конференций (Weighing batcher modernization. Bulletin of scientific conferences). 2018, No. 12-3 (40), pp. 55-56. (In Russian)

[6] Statsenko V. Investigation of the influence of random fluctuations in the flow of bulk material on the operation of control systems for dispensers. Colloquium-journal. 2017, Vol. 11 (1), pp. 53-56

[7] Дмитриев А., Зинуров В., Дмитриева О., Лорай Ф. Оптимизация конструкционных параметров дозатора в системе пневмотранспорта мелкодисперсных материалов. Вестник Технологического университета (Optimization of the design parameters of the dispenser in the pneumatic conveying system for fine materials. Bulletin of the Technological University). 2017, Vol. 20 (17), pp. 39-41. (In Russian)

[8] Егоров В. Б. Анализ технологических линий производства комбикормов как объектов управления. Зернові продукти і комбікорм (Analysis of feed production lines as control objects. Grain products i mixed feed). 2013, Vol. 3 (51), pp. 47-54. (In Ukrainian)

[9] Kadlec K. Measurement of process variables in sugar industry: Weight measurement - industrial weighing . Listy Cukrovarnicke a Reparske, Vol. 134 (2), 2018, pp. 82-86

[10] Мишуров Н. Технологии и оборудование для производства комбикормов в хозяйствах: справочник (Technologies and equipment for the production of compound feed on farms: a reference book). Moscow, 2012, 204 p. (In Russian)

[11] Siemens AG. "Weighing systems: Electronic Weighing System, 2017, 120 p.

[12] Chadha G. S., Westbrink F., Schütte T., Schwung A. Optimal dosing of bulk material using massflow estimation and DEM simulation. 2018 IEEE International Conference on Industrial Technology (ICIT), Lyon, 2018, pp. 256-261.

[13] Schulze D. Powders and bulk solids: Behavior, characterizaton, storage and flow. Berlin: Springer, 2008, 98 p.

[14] Schulze D. Flow properties of bulk solids. Powders and Bulk solids: Behavior, characterization, storage and flow, 2008, pp. 35-74.

[15] Imole O. I., Krijgsman D., Weinhart T., Magnanimo V., Chavez ' Montes B. E., Ramaioli M., Luding S. Experiments and discrete element simulation of the dosing of cohesive powders in a simplified geometry. Powder Technology. Vol. 287, 2016, pp. 108-120.

[16] Shimizu Y., Cundall P. A. Three-Dimensional DEM Simulations of Bulk Handling by Screw Conveyors, Journal of Engineering Mechanics, vol. 127(9), 2001, pp. 864-872.

[17] Aufderheide D., Di Matteo L. Dynamic Dosing. World Cement. Vol. 12, 2014, pp. 63- 68

[18] Mikulec, M. Průmyslová vážicítechnika. ( Industrial weighing technology).Vydal Schenck, spol. s r. o., Praha, 2000 (In Czech)

[19] Adamovics A., Platace R., Gulbe I., Ivanovs S. The content of carbon and hydrogen in grass biomass and its influence on heating value. Engineering for rural development. Vol. 17, 2018, pp. 1277-1281.

[20] Bulgakov V., Ivanovs S., Adamchuk V., Ihnatiev Y. Investigation of the influence of the parameters of the experimental spiral potato heap separator on the quality of work. Agronomy Research. Vol. 15(1), 2017, pp. 44-54.

[21]Záhorská R., Nozdrovický L., Mikulášik L. Implementation of statistical methods and Swot analysis for evaluation of metal waste management in engineering company. Acta Technologica Agriculturae. Volume 19, Issue 4, 2016, pp. 89-95. 